\title{
Relationship of Exclusive Breastfeeding, Complementary Feeding and Nutritional Intake with Stunting in Children in Karanglewas Health Center
}

\author{
$1^{\text {st }}$ Noor Yunida Triana \\ Health Faculty \\ University of Harapan Bangsa \\ Central Java, Indonesia \\ haniwiyana56@gmail.com
}

\author{
$2^{\text {nd }}$ Siti Haniyah \\ Health Faculty \\ University of Harapan Bangsa \\ Central Java, Indonesia noortriana87@gmail.com
}

\begin{abstract}
Stunting is a long-term lack of proteinenergy characterized by a lack of height according to age. The prevalence of stunting in Indonesia is ranked fourth in Asia, with a prevalence of $36.4 \%$. This study was aimed to analyze the relationship of exclusive breastfeeding, complementary food for breast milk (complementary feeding), nutritional intake with stunting in children under five in Karanglewas Health Center. The design of this study was a correlation study with a cross-sectional approach. The study population was all toddlers in Karanglewas Health Center totaled 658 respondents. A sample of 87 respondents was taken by a cluster sampling technique. The instrument used was in the form of an exclusive ASI questionnaire, solids, and food frequency questionnaire. Most respondents experienced the stunting of 44 children $(50.6 \%)$. There was a relationship of exclusive breastfeeding with stunting (p-value 0.004); the relationship between MPASI and stunting (p-value 0.039 ); and there was a relationship between nutritional intake and stunting (p-value 0.001). In conclusion, Factors that influence the incidence of stunting are exclusive breastfeeding, provision of complementary feeding and nutritional intake.
\end{abstract}

Keywords: stunting, exclusive breastfeeding, complementary feeding, nutritional intake, food frequency questionnaire

\section{INTRODUCTION}

Inadequate nutrient intake in infants can be the cause of several nutritional problems, one of which is stunting. Stunting is a long-term lack of protein-energy which is characterized by a lack of height according to age [1]. The prevalence of stunting in Indonesia ranks fourth in

Asia, with a prevalence of $36.4 \%$ [2]. While based on the Basic Health Research (Riskesdas) in 2018 explained that the prevalence of stunting in Indonesia reached $30.8 \%$, reached 28\% in Central Java and reached 20\% in Banyumas Regency [3]. The results of the pre-survey conducted in Karanglewas Sub-District in April showed that stunted toddlers accounted for $19.3 \%$ of the total number of children under five, namely 127 out of 658 toddlers [4]. Stunting must be dealt with immediately because it can adversely affect toddlers. The effects of stunting on infants include increasing the risk of degenerative diseases in the future, disrupting health, education and at the risk of decreasing the quality of learning [5]. Also, stunting has an impact on one of the organs, the brain. Children who experience stunting can experience learning difficulties compared to children who are not stunting [6].
The problem of stunting is influenced by several factors. One of the influencing factors is the intake of breast milk (ASI), intake of complementary foods that are not optimal and lack micro-substances [7]. Breast milk is a special liquid that comes out of the mother's breast for the most perfect, practical, not expensive and clean baby food. Breast milk is needed for infants to meet nutritional needs in the first 6 months of life [8]. Breast milk contains carbohydrates, fats, proteins, multivitamins, water, creatinine and minerals that are easily absorbed perfectly [9].

In addition to exclusive breastfeeding, toddlers also obtain nutrients from complementary foods (MPASI) as advanced nutrition. The quantity and quality of MPASI can influence the linear growth associated with stunting [10]. Furthermore, another important thing that affects stunting is nutrition intake. Nutrients that contain nutrients are very important for the growth and development of infants. Nutrients are determined by choosing the right type of food. There are 6 nutrients needed by the body, namely carbohydrates, fats, proteins, vitamins, and minerals. Carbohydrates as the main energy source for activity. Fat is useful as a backup source of energy. Protein is a substance for building cells and replacing damaged body cells. This shows the importance of adequate nutrition for toddlers [11].

Based on this phenomenon, it can be seen that Exclusive breast milk, MPASI, and nutrient intake are very important for toddler growth. More research on this issue is expected to be information to prevent the occurrence of stunting.

\section{METHOD}

This study employed a descriptive correlation research design, with a cross-sectional approach. This research used a cluster sampling technique by selecting 10 integrated health posts in Karanglewas area. The number of samples was calculated using the Slovin formula and 87 respondents were obtained.

The instrument used was a questionnaire about Exclusive Breastfeeding and weaning food (MPASI), as well as a food frequency questionnaire to obtain nutritional intake data. Analysis of the data used was univariate analysis of the frequency distribution of exclusive breastfeeding, MPASI and nutrient intake measured by a daily nutrition calculation program. Furthermore, the bivariate analysis employed was Chi-Square 


\section{RESULTS AND DISCUSSION}

1. The Incidence of Stunting in Toddlers in Karanglewas Health Center

The incidence of stunting in children under five in Karanglewas Health Center is shown in the table below:

Table 1. Incidence of Toddler Stunting (n: 87)

\begin{tabular}{lcc}
\hline \multicolumn{1}{c}{ Event stunting } & Frequency & Percentage \\
\hline Stunting & 44 & .6 \\
Normal & 43 & .4 \\
\hline \multicolumn{4}{c}{ Table 1 shows that the majority of respondents } \\
stunted was 44 children $(50.6 \%)$.
\end{tabular}

Based on research it can be seen that the incidence of stunting in children under five in Karanglewas Health Center was 50.6 percent. This shows the prevalence of stunting in children under five in Karanglewas Health Center has exceeded the limit set by WHO by $20 \%$. The prevalence of stunting in Indonesia ranks fourth in Asia, with a prevalence of $36.4 \%$ [2]. This prevalence is also higher than the research conducted by [13] which revealed that the stunting percentage reached 26.9 percent.

The high prevalence of stunting can be caused by several factors. The factors that cause stunting are the same as the factors that cause toddlers to experience nutritional problems. One such factor is a nutrient deficiency.

Stunting that occurs in children is the impact of nutrient deficiency during the first thousand days of life. Growth and development disorders in children who are malnourished can cause problems in the future if they do not get intervention early on [14].

This is consistent with [15] which states that the determinants of stunting in children aged 12 to 60 months in Barru Regency, South Sulawesi are energy intake and macronutrients such as carbohydrates, proteins, and fats. On the contrary, the intake of micronutrients that affect the incidence of stunting is the intake of vitamin A and Zinc.

Based on an expression from the United Nations Children's Fund (UNICEF) which states that the problem of stunting is caused by many factors, where these factors are related. There are three main factors that cause stunting: unbalanced food intake, which is related to nutrient content. These nutrients include carbohydrates, fats, proteins, minerals, and vitamins. Two other factors are a history of low birth weight and a history of the disease [16].

2. Description of Exclusive Breastfeeding

Table 2. Frequency Distribution of Exclusive Breastfeeding (n: 87)

\begin{tabular}{ccc}
\hline Exclusive & Frequency & Percentage \\
\hline Yes & 41 & 47.1 \\
No & 46 & 52.9 \\
\hline
\end{tabular}

Based on Table 2, most of the mothers in the Karanglewas Health Center did not give exclusive breastfeeding to toddlers, amounting to 46 respondents $(52.9 \%)$.

The results showed that some toddlers in Karanglewas Health Center did not get exclusive breastfeeding, which was $52.9 \%$, while others received exclusive breastfeeding, which amounted to $47.1 \%$. This is consistent with which explains that more than half of children under five in Kalibaru village did not get exclusive breastfeeding $(58.7 \%)$, while the remaining $41.3 \%$ of children under five were given exclusive breastfeeding.

Exclusive breastfeeding is only giving breast milk to babies from babies born until the age of 6 months, except drugs, vitamins, and minerals. During the first 6 months, babies are not given food and other drinks besides breast milk [18]. Most of the children in Karanglewas Health Center did not get exclusive breastfeeding because before 6 months they had received formula milk or additional food such as porridge and banana.

This is consistent with research conducted by [19] that some respondents, namely $56.7 \%$ did not give exclusive breastfeeding. Respondents gave formula milk to children, besides giving breastfeeding. Some of the reasons respondents gave formula milk were: reduced milk production, the baby's desire for breast milk and the work of mothers outside the home.

\section{Overview of Giving MPASI}

Table 3. Frequency Distribution of Giving MPASI (n: 87)

\begin{tabular}{ccc}
\hline MPASI & Frequency & Percentage \\
\hline Nice & 48 & 55.2 \\
Deficient & 39 & 44.8 \\
\hline
\end{tabular}

Table 3 shows the provision of MPASI to children under five in Karanglewas Health Center, mostly in the good category of 48 respondents $(55.2 \%)$.

This study illustrates the proportion of giving MPASI to children under five in Karanglewas Public Health is mostly in the good category that is $55.2 \%$. Although most toddlers do not get exclusive breastfeeding, toddlers get the right MPASI. This is more likely to the way of giving a variety of foods ranging from variations and stages of giving MPASI according to age. Toddlers get MPASI gradually from thick liquid consistency foods to the mushy rice. It's just that the time of the gift is right and something is too fast. The weaning food (MPASI) are advanced nutrition and complementary foods. The requirements for giving the right MPASI include on time, safe, adequate and given in the right way [10].

4. Overview of Nutrition Intake

Table 4. Distribution of Nutrition Intake Frequencies (n: 87)

\begin{tabular}{cccc}
\hline Nutrition Percentage & Frequency & Percentage \\
\hline Calorie & Adequate & 48 & 55.2 \\
\cline { 2 - 4 } Intake & Low & 39 & 44.8 \\
\hline Protein & Adequate & 48 & 55.2 \\
\cline { 2 - 4 } intake & Low & 39 & 44.8 \\
\hline
\end{tabular}

Based on table 4 it can be seen that nutrition intake for children under five in Karanglewas Health Center in the category of quite a several 48 respondents $(55.2 \%)$.

The results of this study suggested that the majority of children under five in Karanglewas Health Center got an adequate nutritional intake of $55.2 \%$, while the remaining low nutritional intake of $44.8 \%$. This is 
consistent with research conducted on toddlers in the Maluku region which explains that most toddlers get an adequate nutritional intake of $73.6 \%$ [20].

Nutrient intake is related to nutritional intake. Adequate nutrition is needed by toddlers to ensure optimal growth and development [21]. Nutritional intake in this study included calorie intake and protein intake. Nutritional intake is divided into two categories, namely low nutrient intake $(<100 \%$ RDA $)$ and Adequate ( $\geq 100 \%$ RDA). This standard is in accordance with [17] regarding energy intake associated with the incidence of stunting.

5. Relationship between Exclusive Breastfeeding and Stunting in Karanglewas Health Center

Table 5. Relationship of Exclusive Breastfeeding with Stunting (n: 87)

\begin{tabular}{cccccc}
\hline $\begin{array}{l}\text { Exclusive } \\
\text { Breastfedding }\end{array}$ & Stunting & Normal & p-value \\
\hline Yes & 14 & 16.1 & 27 & 1.0 & 0.004 \\
No & 30 & 34.5 & 16 & 8.4 & \\
\hline
\end{tabular}

Based on table 5 it is known that the proportion of children under five who did not get exclusive breastfeeding stunted more by $34.5 \%$ (30) compared to toddlers who received exclusive breastfeeding by $16.1 \%$ (14). Statistical test results showed a significant relationship between exclusive breastfeeding and stunting in infants in Karanglewas health center ( $p$-value 0.004).

Bivariate analysis in this study showed that the frequency distribution of children under five who did not get Exclusive ASI experienced more stunting, namely $34.5 \%$ compared to toddlers who received Exclusive breastfeeding (16.1\%). The statistical test shows p-value 0.004 , thus it can be concluded that there was a significant relationship between exclusive breastfeeding and the incidence of stunting in infants in Karanglewas Health Center. This is the following research conducted by [22] which stated that there was a significant relationship between exclusive breastfeeding and the incidence of stunting toddlers aged 6-23 months in Lampung Province. Based on the analysis, the value of $\mathrm{OR}=2.808$ was obtained, meaning that babies who got exclusive breastfeeding had a chance of being stunted 2.808 times compared to toddlers who are exclusively breastfed.

Toddlers who are not more than 6 months old have an imperfect digestive tract, so they cannot receive food other than breast milk. If the baby is not ready but has received additional food, then this can interfere with growth, so that it can cause stunting.

Growth and development in infancy require a balanced and relatively large supply of nutrients. But the ability of babies is limited by the baby's digestive tract which has not yet reached the mature stage. The only food that can meet the needs during the first months and following the state of the baby's digestive tract is breast milk [23].

The mother does not understand that breast milk contains substances that are not found in formula milk. According to [24], breast milk is a liquid that contains immunology such as immunoglobulins that can prevent disease; secretory substances capable of neutralizing E. coli bacteria and other viruses in the digestive tract; and lactoferrin which functions to bind iron. Breast milk contains protein and other substances that cause breast milk to be more easily absorbed compared to formula milk.

Based on these contents, it is clear why toddlers who do not get exclusive breastfeeding are more likely to experience stunting compared to toddlers who receive exclusive breastfeeding. It would be better if toddlers get breast milk until the age of 2 years.

6. Relationship between the provision of MPASI and the incidence of stunting in Karanglewas Public Health Center

Table 6. Relationship between the provision of MPASI and the incidence of stunting in Karanglewas Public Health Center (n: 87)

\begin{tabular}{cccccc}
\hline $\begin{array}{l}\text { Giving } \\
\text { MPASI }\end{array}$ & Stunting & \multicolumn{2}{l}{ Normal } & P value \\
\hline Nice & 17 & 19.5 & 31 & 35.6 & 0.002 \\
Deficient & 27 & 31.0 & 12 & 13.8 & \\
\hline
\end{tabular}

Based on table 6 , it is known that the proportion of children under five who received MPASI did not experience better stunting at $31.0 \%$ (27) compared to toddlers who received MPASI well at $19.5 \%$ (17). Statistical test results show that there is a significant relationship between giving MPASI and stunting at Karanglewas Public Health Center (p-value 0.002).

The results of the bivariate analysis showed that toddlers who received poor MPASI experienced more stunting, amounting to $31.0 \%$ compared to toddlers who got good MPASI $19.5 \%$. The statistical test shows that there is a significant relationship between giving MPASI to children under five with stunting at Karanglewas Health Center. This is consistent with [25] which states that the results of hypothesis testing on 104 respondents showed a significant relationship between early MPASI administration and stunting (p-value 0,000).

World Health Organization (WHO) and UNICEF in its provisions require infants aged 6-23 months to get adequate MPASI with the provisions that they can receive a minimum of 4 or more than 7 types of food (cereals/tubers, nuts, nuts, dairy products, eggs, a source of protein, vegetables, and fruits rich in vitamin A, vegetables and other fruits). Besides, babies must get MPASI with the right frequency (6-8 months of age: $2 \mathrm{x} /$ day or more, while ages 9-23: $3 \mathrm{x} /$ day or more, for babies 6-23 months who are not breastfed: $4 \mathrm{x} /$ more). If MPASI is given according to the provisions, then the growth of the baby will be optimal and stunting does not occur [26].

7. Relationship of Nutrition Intake with Stunting Event in Karanglewas Health Center

Table 7. Relationship of Nutrition Intake with Stunting Event (n: 87)

\begin{tabular}{lllllll}
\hline \multirow{2}{*}{ Nutrition Intake } & \multicolumn{2}{c}{ Stunting } & \multicolumn{2}{c}{ Normal } & p- \\
\cline { 3 - 6 } & & $\mathrm{n}$ & $\%$ & $\mathrm{n}$ & $\%$ & value \\
\hline Calories & $\begin{array}{l}\text { Adequa } \\
\text { te }\end{array}$ & 17 & 19.5 & 48 & 55.2 & \multirow{2}{*}{0.002} \\
\cline { 2 - 6 } & Low & 27 & 31.0 & 39 & 44.8 & \\
\hline Protein & $\begin{array}{l}\text { Adequa } \\
\text { te }\end{array}$ & 17 & 19.5 & 48 & 55.2 & \multirow{2}{*}{0.002} \\
\cline { 2 - 6 } & Low & 27 & 31.0 & 39 & 44.8 & \\
\hline
\end{tabular}

Table 7 shows that toddlers who got low-calorie 
intake, had a greater risk of stunting, which was $31.0 \%$ compared to toddlers who got enough calorie intake, which was $19.5 \%$. Likewise, toddlers who got low protein intake, had a greater risk of stunting, which was $31.0 \%$ compared to toddlers with an adequate protein intake that was $19.5 \%$. Statistical test results showed that there was a significant relationship between nutritional supply and the incidence of stunting among children under five in Karanglewas Health Center (p-value 0.002).

Following bivariate analysis, it can be seen that toddlers who got nutritional intake including low calories and protein tended to experience stunting by $31.0 \%$ compared to toddlers who got adequate nutritional intake $(19.5 \%)$. This is following the study of [27] which explained that low energy consumption in the group of stunted children can be caused by the frequency and amount of feeding, low energy density, and less nutritious food.

The results showed that there was a significant relationship between nutrient intake and the incidence of stunting in children under five in Karanglewas Health Center indicated by $p$-value 0.002 . This study is in line with the research of [28] which explains that there is a relationship of nutritional status with energy intake ( $p$ value 0.015 ) which includes intake of calories, protein, fat, and zinc. This study is also in line with [29] which explains that there is a relationship between the level of energy consumption and nutritional status in children. Strength or energy in the human body arises because of the burning of nutrients from carbohydrates, proteins, and fats. So the body needs enough nutrients to carry out the combustion process. The better the energy consumption of toddlers, the better the nutritional status of toddlers.

Protein plays a very important role in the growth of toddlers. This is because protein has a function as the formation of structural components, growth, and formation of antibodies [30]. In addition to protein, fat, and carbohydrate related to nutritional status because fat contains essential fatty acids that play a role in regulating health [31].

\section{CONCLUSIONS}

There is a significant relationship between exclusive breastfeeding with the incidence of stunting in infants in Karanglewas Health Center with a p-value of 0.004 . There is a significant relationship between the weaning food with the incidence of stunting in infants in Karanglewas Health Center with p-value 0.002. There is a significant relationship between nutrient intake and the incidence of stunting in children under five in Karanglewas Health Center with p-value 0.002. Thank you to Karanglewas Health Center that permitted this study and all of the respondents.

\section{REFERENCES}

E. Whitney and S. R. Rofles, Understanding Nutrition, 15th ed. United States: Thomson Wadswoth, 2019.

W. H. Organization, "World Health Statistic 2016: Monitoring Health for the SGDs, Sustainable Development Goals.," WHO Press, 2016.
Dasar," Jakarta, 2018.

[4] Puskesmas Karanglewas, "Data Balita Stunting di Puskesmas Karanglewas,” Purwokerto, 2018.

[5] Kusuma and Nuryanto, "Faktor Risiko Kejadian Stunting pada Anak Usia 2-3 Tahun (Studi di Kecamatan Semarang Timur)," J. Nutr. Coll., vol. 2, no. 4, 2013.

[6] I. Picauly, D. Sarci, and M. Toy, "ANALISIS DETERMINAN DAN PENGARUH STUNTING TERHADAP PRESTASI BELAJAR ANAK SEKOLAH DI KUPANG DAN SUMBA TIMUR, NTT (The Determinant Analysis and the Impact of Stunting for School Children School Performance in Kupang and Sumba Timur, NTT)," J. Gizi dan Pangan, vol. 8, no. 72, p. 55-62, 2013.

[7] Y. Subandra, Y. Zuhairini, and J. Djais, "Hubungan pemberian ASI Eksklusif dan Makanan Pendamping ASI terhadap Balita Pendek Usia 2 sampai 5 tahun di Kecamatan Jatinangor," J. Sist. Kesehat., vol. 3, no. 3, pp. 142-148, 2018.

[8] Walyani, Perawatan Kehamilan dan Menyusui Anak Pertama Agar Bayi Lahir dan Tumbuh Sehat. Yogyakarta: Pustaka Baru Press, 2015.

[9] Soetjiningsih, ASI Petunjuk untuk Tenaga Kesehatan. Jakarta: EGC: EGC, 2012.

[10] D. P. Khasanah, H. Hadi, and B. A. Paramashanti, "Waktu pemberian makanan pendamping ASI (MPASI) berhubungan dengan kejadian stunting anak usia 6-23 bulan di Kecamatan Sedayu," J. Gizi dan Diet. Indones. (Indonesian J. Nutr. Diet., vol. 4, no. 2, p. 105, 2016.

[11] M. Adriani and B. Wirjatmadi, Peranan Gizi dalam Siklus Kehidupan, 1st ed. Jakarta: Kencana Prenadamedia Group, 2016.

[12] S. Notoatmodjo, Metodologi Penelitian Kesehatan. Jakarta: Rineka Cipta: Rineka Cipta, 2010.

[13] E. Setiawan and R. Machmud, "Artikel Penelitian Faktor-Faktor yang Berhubungan dengan Kejadian Stunting pada Anak Usia 24-59 Bulan di Wilayah Kerja Puskesmas Andalas Kecamatan Padang Timur Kota Padang Tahun 2018," Kesehat. Andalas, vol. 7, no. 2, pp. 275-284, 2018.

[14] Kementerian Kesehatan RI, "Peraturan Menteri Kesehatan Republik Indonesia No.39 Tahun 2016 tentang Pedoman Penyelenggaraan Program Indonesia Sehat," Jakarta, 2016.

[15] Hendrayati and R. Asbar, "Faktor Determinan Kejadian Stunting Pada Usia 12 Sampai 60 Bulan," Media Gizi Pangan, vol. 25, no. 1, pp. 69-76, 2018.

[16] UNICEF, "World Health Organization. The World Bank. UNICEF-WHO 2012-World Bank Joint Child Malnutrition Estimates.," UNICEF, New York; WHO, Geneva; The World Bank, Washington, DC., 2012.

[17] P. Anisa, "FAKTOR - FAKTOR YANG BERHUBUNGAN DENGAN KEJADIAN STUNTING PADA BALITA USIA 25 - 60 BULAN DI KELURAHAN KALIBARU DEPOK TAHUN 2012 UNIVERSITAS INDONESIA FAKTOR FAKTOR YANG BERHUBUNGAN DENGAN KEJADIAN STUNTING PADA BALITA USIA 25 60 BULAN DI KELURAHAN KAL,” Indonesia, 2012.

[18] Kementerian Kesehatan RI, "Laporan Hasil Riset Kesehatan Dasar Indonesia Tahun 2010," K. K. R. Indonesia, Ed. Jakarta: Kementerian Kesehatan RI, 2010.

[19] E. D. Lestari, F. Hasanah, and N. A. Nugroho, "Correlation between Non-Exclusive Breastfeeding and 
Anak Usia 2-3 Tahun," J. Kedokt. Diponegoro, vol. 7, no. 2, pp. 1419-1430, 2018.

Low Birth Weigt to Stunting in Children," Paediatr. Indones., vol. 58, no. 3, pp. 123-127, 2018.

[20] M. Asrar, H. Hadi, and D. Boediman, "Pola Asuh, Pola Makan, Asupan Zat Gizi dan Hubungannya dengan Status Gizi Anak Balita Masyarakat Suku Naulu di Kecamatan Maluku Tengah Provinsi Maluku," Gizi Klin. Indones., vol. 6, no. 2, pp. 84-94, 2009.

[21] et al. Ramli, "Prevalence and Risk Factors for Stunting and Severe Stunting among Under-Five in North Maluku Province of Indonesia," J. BMC Pediatr., vol. 9, no. 64, 2009.

[22] C. Angelina, A. A. Perdana, and Humairoh, "Faktor Kejadian Stunting Balita Berusia 6-23 Bulan di Provinsi Lampung," Dunia Kesmas, vol. 7, no. Nomor 7, pp. 127-134, 2018.

[23] R. Haryono and S. Setianingsih, Manfaat ASI Eksklusif untuk Buah Hati Anda. Yogyakarta: Gosyen Publishing, 2014.

[24] A. B. Nirwana, ASI dan Susu Formula: Kandungan Manfaat ASI dan Susu Formula. Yogyakarta: Nuha Medika, 2014.

[25] N. Y. Prihutama, F. A. Rahmadi, and G. Hardaningsih, "Pemberian Makanan Pendamping Asi Dini Sebagai Faktor Risiko Kejadian Stunting Pada
[26] Kementerian Kesehatan RI, "Pusdatin: buletin stunting," Kementeri. Kesehat. RI, vol. 1, p. 2, 2018.

[27] Fitri, "Berat Lahir sebagai Faktor Dominan Terjadinya Stunting pada Balita (12-59 Bulan) di Sumatera (Analisis Data Riskesdas 2010)," Indonesia, 2012.

[28] U. Azmy and L. Mundiastuti, "Nutrients Consumption of Stunted and Non-stunted Children in Bangkalan," Amerta Nutr., vol. 2, no. 3, pp. 292-298, 2018.

[29] R. K. Nagari and T. S. Nindya, "Tingkat Kecukupan Energi , Protein Dan Status Ketahanan Pangan Rumah Tangga Berhubungan Dengan Status Gizi Anak Usia 68 Tahun Levels Adequacy of Energy and Protein and Household Food Security Status with Nutritional Status of Children Aged 6-8 Years," J. Amerta Nutr., pp. 189197, 2017.

[30] D. Damayanti, Ilmu Gizi Teori dan Aplikasi. Jakarta: Buku Kedokteran EGC, 2017.

[31] Hardiansyah and I. D. N. Supariasa, Ilmu Gizi: Teori dan Aplikasi. Jakarta: EGC: Buku Kedokteran EGC, 2017. 